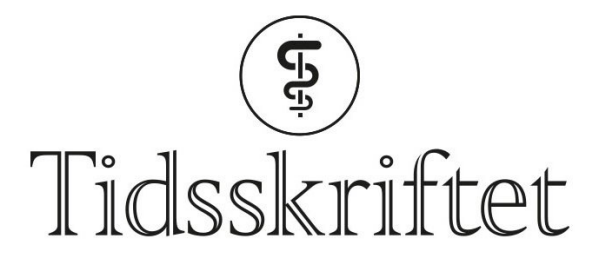

DEN NORSKE LEGEFORENING

\title{
Én antistoffinjeksjon beskytter mot RS-virus
}

FRA ANDRE TIDSSKRIFTER

TORBJØRN ØYGARD SKODVIN

Tidsskriftet

En enkelt injeksjon med monoklonalt antistoff ga kraftig reduksjon i antall infeksjoner og sykehusinnleggelser grunnet RS-virus blant spedbarn.

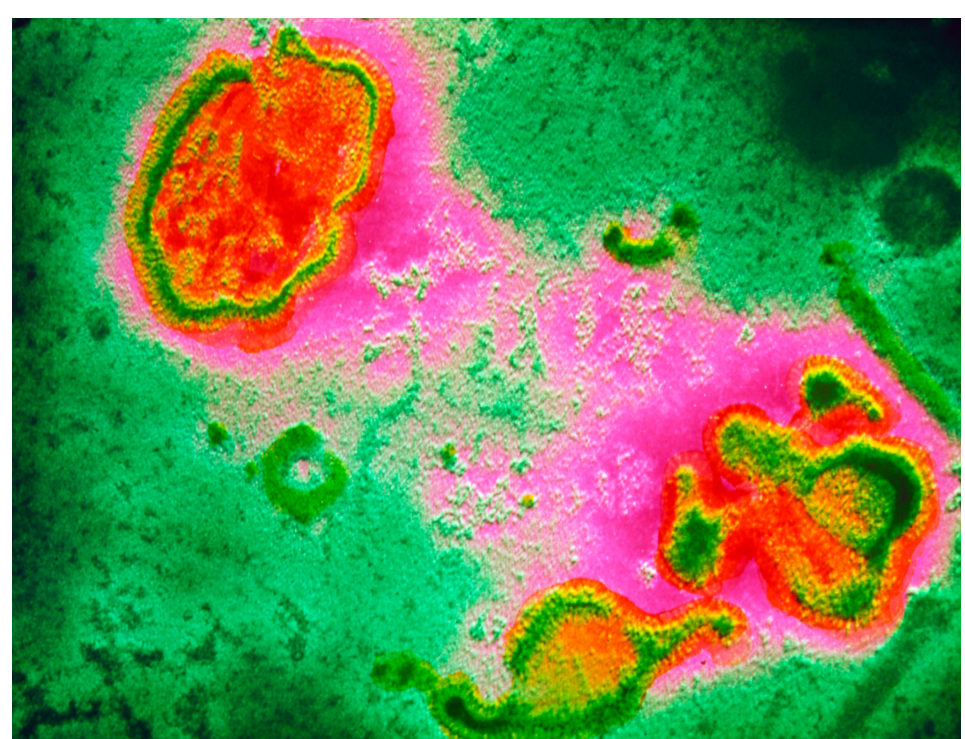

Virioner fra respiratorisk syncytialvirus. Illustrasjonsfoto: Science Photo Library / NTB

Respiratorisk syncytialvirus (RS-virus) forårsaker årlige epidemier av luftveisinfeksjoner. Spedbarn under seks måneders alder er særlig sårbare, og i lav- og mellominntektsland er infeksjon med RS-virus en viktig dødsårsak. Forskning gjennom flere tiår har ikke lykkes i å fremstille en god og sikker vaksine.

En multinasjonal studie har undersøkt effekten av et monoklonalt antistoff med halveringstid på 6o dager, nirsevimab, som binder seg til RS-viruset (1). Rundt 1500 friske, men premature spedbarn, født i uke 29-34, ble randomisert til å få enten nirsevimab eller placebo som én injeksjon i begynnelsen av en sesong for RS-virus.

I løpet av de neste 150 dagene var det 70 \% færre ( $95 \%$ KI 52 til 81\%) av spedbarna som hadde fått antistoff, som trengte helsehjelp for luftveisinfeksjon grunnet RS-virus. Andelen sykehusinnleggelser for RS-virusassosiert luftveisinfeksjon var 78 \% lavere ( $95 \% \mathrm{KI} 52$ til $90 \%)$ i antistoffgruppen. Det var ingen forskjell i bivirkninger mellom de to gruppene. 
- Resultatene fra denne store studien er svært lovende, sier seksjonsoverlege Claus Klingenberg ved Barne- og ungdomsavdelingen ved Universitetssykehuset Nord-Norge.

- Kun én dose av dette antistoffet ser ut å gi effektiv beskyttelse i den alderen RS-viruset gir mest alvorlige infeksjoner. Det gjenstår imidlertid å se om prisen blir så høy at medikamentet ikke vil bli finansiert av det offentlige helsevesenet, men kun bli tilgjengelig for dem som har råd, sier Klingenberg.

LITTERATUR:

1. Griffin MP, Yuan Y, Takas T et al. Single-dose nirsevimab for prevention of RSV in preterm infants. N Engl J Med 2020;383: 415-25. [PubMed][CrossRef]

Publisert: 23. november 2020. Tidsskr Nor Legeforen. DOI: 10.4045/tidsskr.20.0811

(C) Tidsskrift for Den norske legeforening 2020. Lastet ned fra tidsskriftet.no 